\title{
Pakistan-India Trade Potential and Issues
}

\section{Zareen F. Naqui*}

\begin{abstract}
Pakistan and India are the two largest economies in South Asia with very low levels of bilateral trade. This has been the result of border disputes and political tensions, but also of inward-looking import-substitution growth strategies. Trade (including official and unofficial) between the two countries stood at around US\$ 2.5-2.6 billion in 2007/08 but it could potentially be as much as US\$ 5-10 billion or two to four times its current levels. The Composite Dialogue Process (CDP) has led to substantial improvements in political relations over the last 5 years and trade relations have shown positive outcomes as well. This paper recommends that the process be strengthened further by restarting the stalled CDP, Pakistan granting most favored nation (MFN) status to India, continuing to reduce impediments to trade and trade logistics, and perhaps even considering the possibility of a free trade agreement (FTA) with India.
\end{abstract}

JEL Classification: F19, 024.

Keywords: Bilateral trade, Pakistan, India, competitiveness.

\section{Introduction}

Pakistan and India are the two 1argest economies in South Asia. ${ }^{1}$ Together, they account for 90 percent of the gross domestic product (GDP) and 85 percent of the population of the region. They share a long contiguous border, have similar cultures, and, in the not-too-distant past, enjoyed wellintegrated transport and market links. If we look at neighboring countries similar in size to India and Pakistan in terms of population or current GDPsuch as Malaysia and China or Brazil and Argentina-bilateral trade accounts for 2.2 percent and 10.2 percent, respectively, of world trade in these countries. The case of Pakistan and India is quite different. In 2007/8, the share of total trade in goods between Pakistan and India was less than 0.5 percent of their combined trade with the rest of the world.

* Director of Institutional Research at the University of the Fraser Valley in British Columbia, Canada.

${ }^{1}$ We use the definition of South Asia used by the World Bank. The countries in this region include: Afghanistan, Bangladesh, Bhutan, India, Maldives, Nepal, Pakistan, and Sri Lanka. 
The abysmally low level of Pakistan-India bilateral trade is not only a result of border disputes and political tensions, but also of inward-looking import-substitution growth strategies. This has rendered South Asia among the least integrated economic regions in the world. Between 1980 and 2005, intraregional trade as a share of total trade within South Asia only rose from 3 to 4 percent, whereas in East Asia - a region of comparable size in population and GDP-intraregional trade more than doubled from 6 to 14 percent. $^{2}$ It is striking that, over the same period, South Asia's worldwide exports grew from only $\$ 12$ billion to $\$ 126$ billion-a tenfold increase-while East Asia's jumped from $\$ 48$ billion to over $\$ 1$ trillion-a twentyfold increase. ${ }^{3}$

Bilateral trading relations between India and Pakistan were not always so limited. In $1950 / 51^{4}, 4$ years after the partition of the Indian subcontinent, bilateral trade stood at $\$ 147$ million, or close to 5 percent of their total world trade. Over the past 55 years, both economies have grown significantly in terms of GDP and per capita income. The combined GDP of India and Pakistan was close to a trillion US dollars in 2005/06, while their trade (exports and imports) of goods and services with the world accounted for US\$361 billion, or around 39 percent of their combined GDP in that year (see Figures 1-4). However, bilateral trade accounted for less than a billion US dollars in $2005 / 06$, or only 0.3 percent of their combined trade in goods and services with the world. Trade between India and Pakistan is miniscule compared to what it could potentially be, which by estimates could be as high as US\$10 billion or $2 \%$ of the combined merchandize trade with the world. Thus, both countries have missed the opportunity of anchoring their own growth and competitiveness on bilateral trade. Being the two largest economies in South Asia, regional trade and economic integration too has suffered considerably compared to other regions of the world.

This paper discusses the issues that prevent Pakistan and India from reaching their full potential of bilateral trade. It also suggests measures that are necessary to continue to promote bilateral trade, not only to engender growth in the two countries, but also to strengthen the region's international competitiveness.

\footnotetext{
${ }^{2}$ Percentages are calculated as exports plus imports of developing countries in each region as shares of their total exports plus imports.

${ }^{3}$ Data are gross exports from developing countries in East and South Asia in current US dollars, taken from the UN Comtrade database.

${ }^{4}$ Wherever we have used years that follow the format $1997 / 98$ or $2004 / 05$, we mean fiscal years. Unless otherwise specified, calendar years are used without the prefix fiscal years.
} 
Figure 1: Economy Size GDP (US\$ billion)

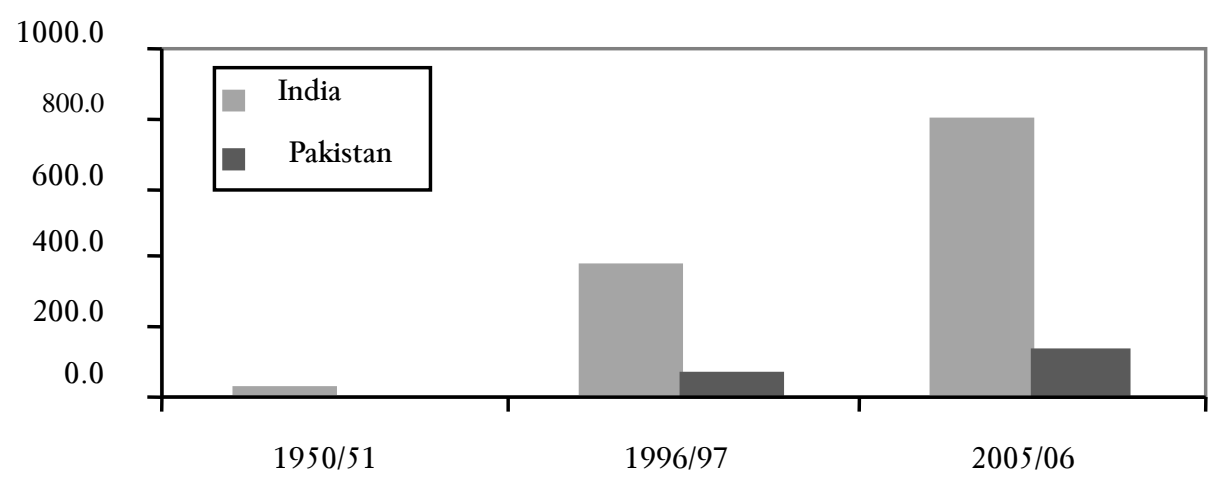

Figure 2: Per Capita Income (US\$)

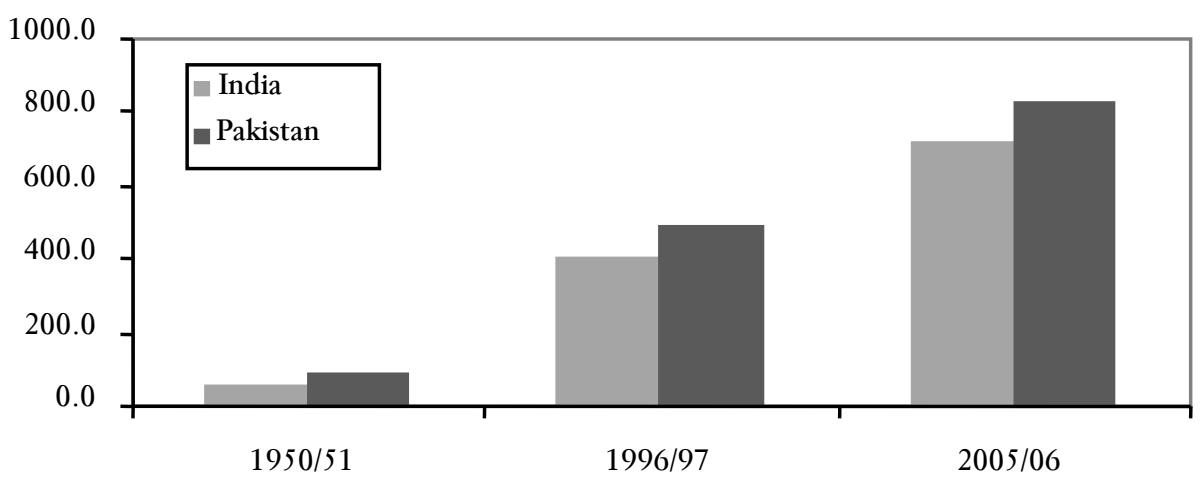

Figure 3: Trade in Goods and Services (\% of GDP)

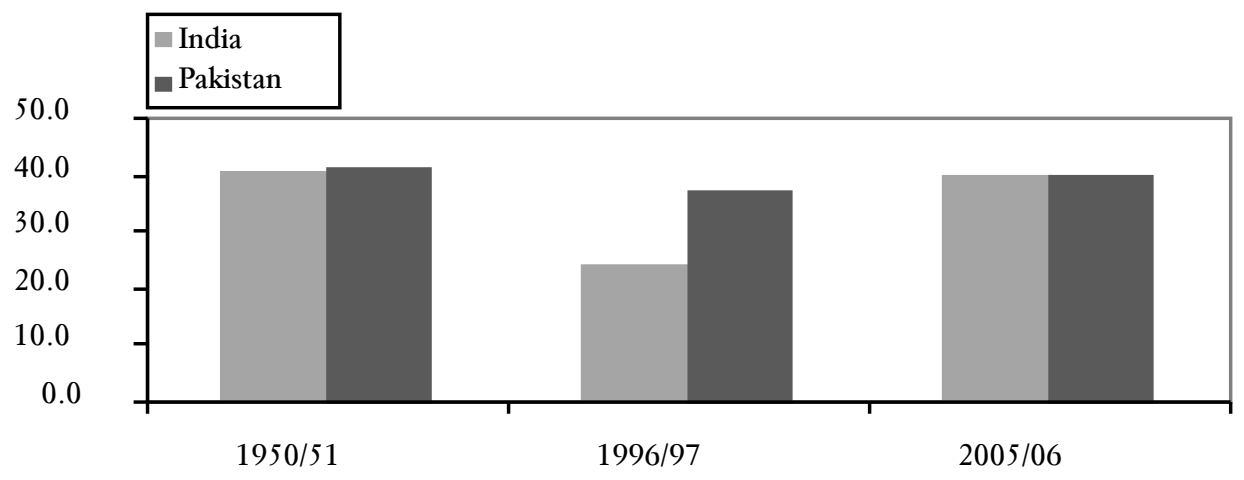


Figure 4: Bilateral Trade between India and Pakistan in Goods (US\$ million)

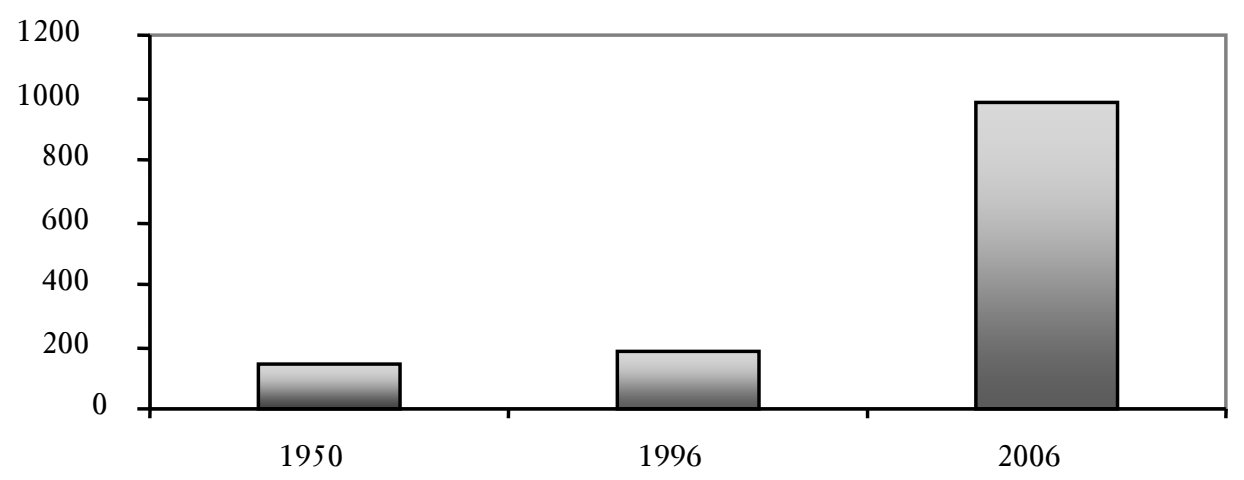

Source: The World Development Indicators database, The World Bank.

\section{Key Issues Constraining Pakistan-India Trade}

Political tension and import-substitution policies to promote industrialization have resulted in insufficient commitment to regional integration. In this paper, we focus on policies and constraints from Pakistan's perspective, although many of the policies and issues discussed apply equally to India.

\section{Political Tensions}

Political conflict is the key element that has obstructed bilateral trade between India and Pakistan. At the time of independence in 1947, almost three fifths of Pakistan's total exports were directed to the Indian market, and one third of its imports came from India (Sangani and Schaffer 2003). This began to change when Pakistan refused to devalue its currency after India's devaluation in 1949, and later imposed import restrictions. Since then, bilateral trade has declined sharply during periods of conflict or heightened tension (see Figure 5). It increases slowly as political relations improve.

Trade between India and Pakistan almost ceased altogether from the mid-1960s to the mid-1970s, due to the 1965 India-Pakistan war and the 1971 East Pakistan war, which led to the creation of Bangladesh. More recently, bilateral relations between the two countries became extremely tense after the 1999 Kargil war, as well as after an attack on the Indian parliament building in December 2001. Overall, it has taken 4 decades for the trade volume (measured in nominal terms) between the two countries to exceed the levels reached in the early 1950s. 
Figure 5: Pakistan-India Trade vs. Political Tension

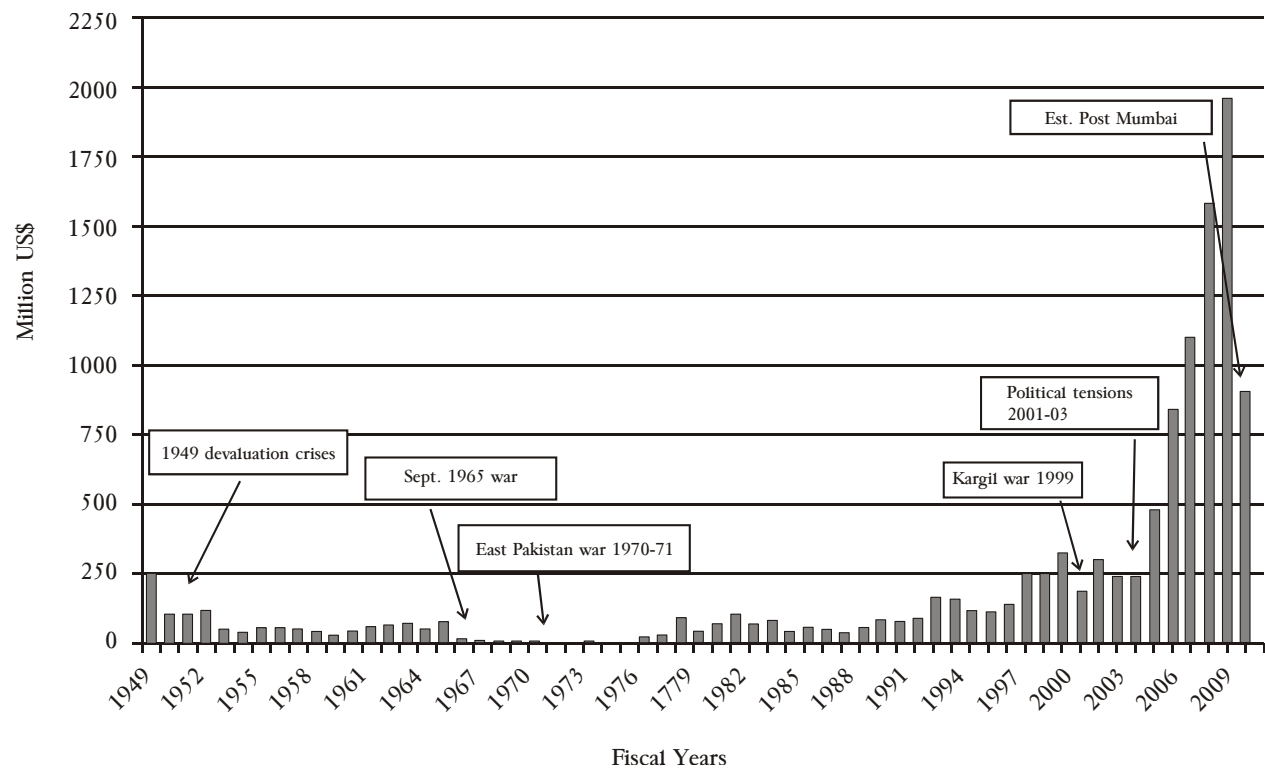

Source: 50 Years of Pakistan in Statistics, and Ministry of Commerce, Government of Pakistan.

Note: Trade is measured as a sum of exports and imports in nominal US dollar values.

Although it is still too early to assess the impact of heightened political tension on trade statistics after the Mumbai terrorist attacks (November 26-29, 2008), indications are that bilateral trade may be another victim of this unfortunate episode. A recent survey of Indian exporters by the Federation of Indian Chambers of Commerce and Industry (FICC) estimated that bilateral trade might be reduced by as much as $60 \%$ due to a combination of the international financial crisis and Mumbai terrorist attacks.' According to this survey, Indian businessmen have refused to travel to Pakistan after the Mumbai attacks, even to sign previously agreed contracts, let alone strike new business deals. Pakistani businesses have reportedly expressed a similar reluctance to travel to India. Key sectors expected to be affected by these developments include: textiles and clothing, textile machinery, cotton, agricultural products (particularly cereals), and steel and chemicals.

5 “60\% fall in Indo-Pak trade post 26/11: FICCI”, March 12, 2009. Retrieved from: http://www.financialexpress.com/news/60-fall-in-indopak-trade-post-26-11ficci/433231/. 


\section{Import Substitution Policies}

Economic policies in both India and Pakistan were inward-looking immediately after independence and until the early 1990s. Initial Indian economic policy was influenced by socialist ideals. It placed a heavy emphasis on protectionism, import-substituting industrialization, and state intervention in labor and financial markets, a large public sector, business regulation, and central planning. Steel, mining, machine tools, water, telecommunications, insurance, and electrical plants, among other industries, were effectively nationalized in the mid-1950s. Until 1990, elaborate licenses, regulations, and bureaucratic hurdles, commonly referred to as "License Raj," were required to set up businesses. The Indian rupee was inconvertible and high tariffs and import licensing prevented foreign goods reaching the market. The government also prevented firms from laying off workers or closing factories. Planning and the state, rather than markets, determined key economic decisions related to production and investment.

Pakistan's international competitiveness too has historically suffered from inward-looking import substitution policies and the protection of domestic industries. The anti-export bias inherent in high import tariffs, a poor investment climate, the high cost of doing business, low labor productivity particularly in the manufacturing sector, shortages of skilled workers, distortions in land markets, and excessive business regulations have collectively restricted the competitiveness of Pakistani companies. After the dismemberment of the country and serious economic crisis following the 1971 war with India, Pakistan took up economic reforms that included the devaluation of the overvalued rupee and finding new markets for exports. However, during 1972-74 Pakistan nationalized a number of industries, banks, and insurance companies that resulted in a loss of confidence by the private sector and capital flight. Trade and industrial policies remained restricted during the mid-1970s to mid-1980s, although growth remained high due to good agricultural growth and infusion of financial assistance to Pakistan related to the Soviet occupation of Afghanistan. The wars with India and inward-looking policies contributed to the nervousness (sparked by concerns of being swamped by the Indian economy) about opening up Pakistani markets to Indian imports. Instead of looking to the Indian market as an opportunity, many protected stakeholders saw bilateral trade as a threat to their profits.

In the mid- to late 1980s, both the Pakistani and Indian economies went through considerable economic liberalization. In India, the reform process began in the early 1990s with reforms aimed at opening 
international trade and investment, deregulation, initiation of privatization, tax reforms, and inflation-controlling measures. The overall direction of liberalization remained steady even when different political parties won elections and formed governments. The fruits of liberalization reached their peak in 2007, with India recording its highest GDP growth rate of $9 \%$. With this, India became the second-fastest growing major economy in the world, next only to China. India has joined the league of important emerging economies and the G-20 group. According to the Economist: "India counts as one of liberalization's greatest success stories." ${ }^{6}$ However, the reform momentum has been limited in areas that deal with powerful lobbies such as trade unions and farmers, or contentious issues such as reforming labor laws and reducing agricultural subsidies. According to the World Bank, India still faces challenges in public sector reforms, infrastructure, agricultural and rural development, reforms in lagging states, and in dealing with the impact of HIV/AIDS. ${ }^{7}$ There is also considerable room for more wide-ranging and deeper reforms in the trade and investment regimes.

Figure 6: Average Applied MFN Tariff Rates in India and Pakistan

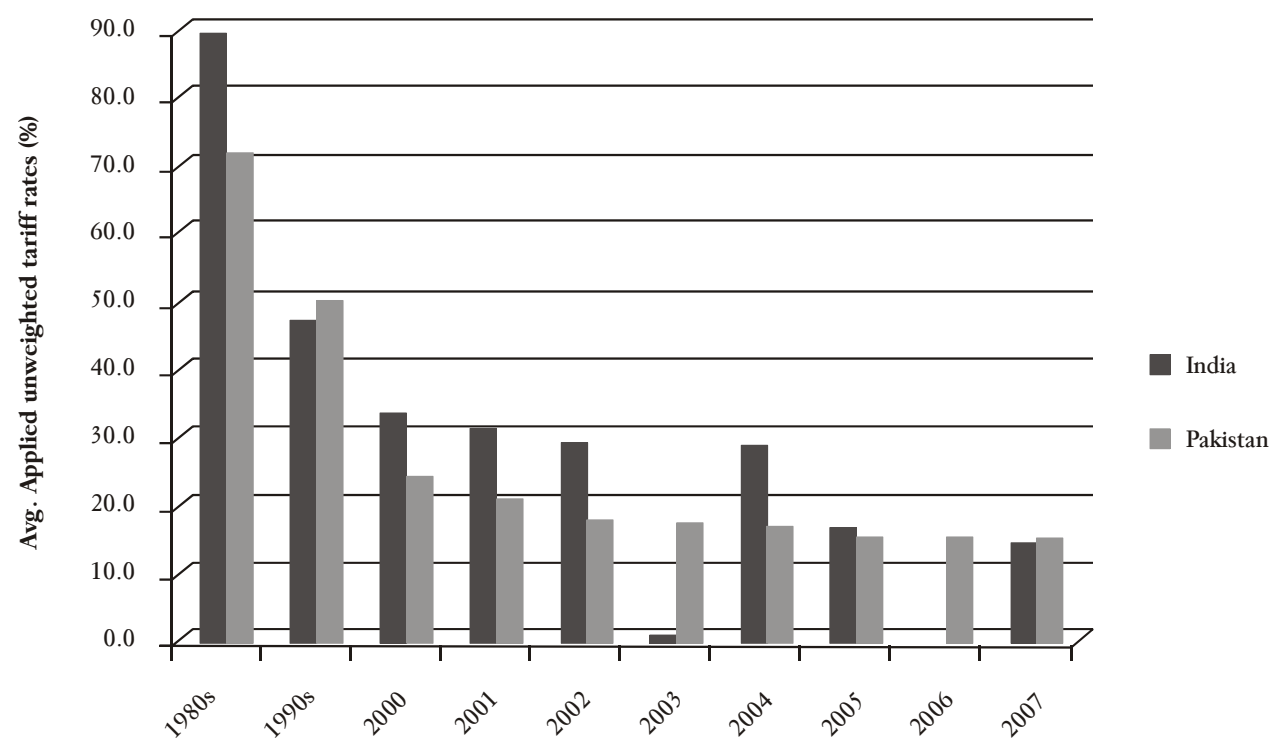

Source: The World Bank, Data on Trade and Import Barriers ${ }^{8}$

\footnotetext{
6 “What’s Holding India Back,” Economist, March 8, 2008, p. 11.

${ }^{7}$ http://go.worldbank.org/0BXQ5J38J0

${ }^{8}$ http://econ.worldbank.org/WBSITE/EXTERNAL/EXTDEC/EXTRESEARCH/0,,conten tMDK:21051044 pagePK:64214825 piPK:64214943 theSitePK:469382,00.html.
} 
Similarly, Pakistan has made good progress on wide-ranging economic and institutional reforms. The pace of reforms was intermittent under political regimes from 1988 to 1999 , but took on serious momentum during Pervez Musharraf's rule in the early 2000s. Pakistan abandoned its decades-old program of import substitution in 1998 and embarked on ambitious economic reforms designed to spur on economic growth through greater integration with the world economy. The average tariff rate fell from close to 70 percent in the 1980s to about $30 \%$ in 2001, and stands now at around 14 percent (see Figure 6). In addition to cutting import tariff rates, the government eliminated quantitative restrictions, regulatory duties, and other para-tariffs, ${ }^{9}$ and several other measures that had restricted trade in the past. Institutional reforms in tax administration and trade facilitation have accompanied the reduction in tariffs. These reforms have left Pakistan in a much better position to pursue preferential liberalization, whether in the context of the South Asian Free Trade Area (SAFTA) or through bilateral agreements. The reforms have also allowed the country to focus on the behind-the-border trade-related reforms ${ }^{10}$ needed to enhance competitiveness. The impact of economic, fiscal, and trade reforms has yielded rewards in terms of improved overall economic performance. The GDP growth rate jumped to 6.4 percent in $2003 / 04,8.6$ percent in $2004 / 05$, and 6.6 percent in 2005/06-compared to around 4 percent during the 1990s-and was projected to be in the 6.5-7.2 percent range in the medium term. However, recent political instability, the impact of the global financial crisis, and governance failures has resulted in a serious economic crisis and a bailout by the International Monetary Fund (IMF) in 2008.

\footnotetext{
${ }^{9}$ Para-tariffs refer to trade regulations that can act as impediments to trade like tariffs do. These could be additional border charges and fees on foreign trade transactions. In many cases, these regulations are levied solely on imports, but not in the same manner as on similar types of domestic products.

${ }^{10}$ Behind-the-border trade-related reforms usually refer to domestic policy measures that support trade. Examples could be major institution-building custom reforms and trade facilitation. Improvements in trade-related infrastructure and provision of efficient competitive trade-related services are other examples of behind-the-border trade-related reforms.
} 
Figure 7: Bilateral Trade between Pakistan and India FYs 1996-2008 ${ }^{11}$

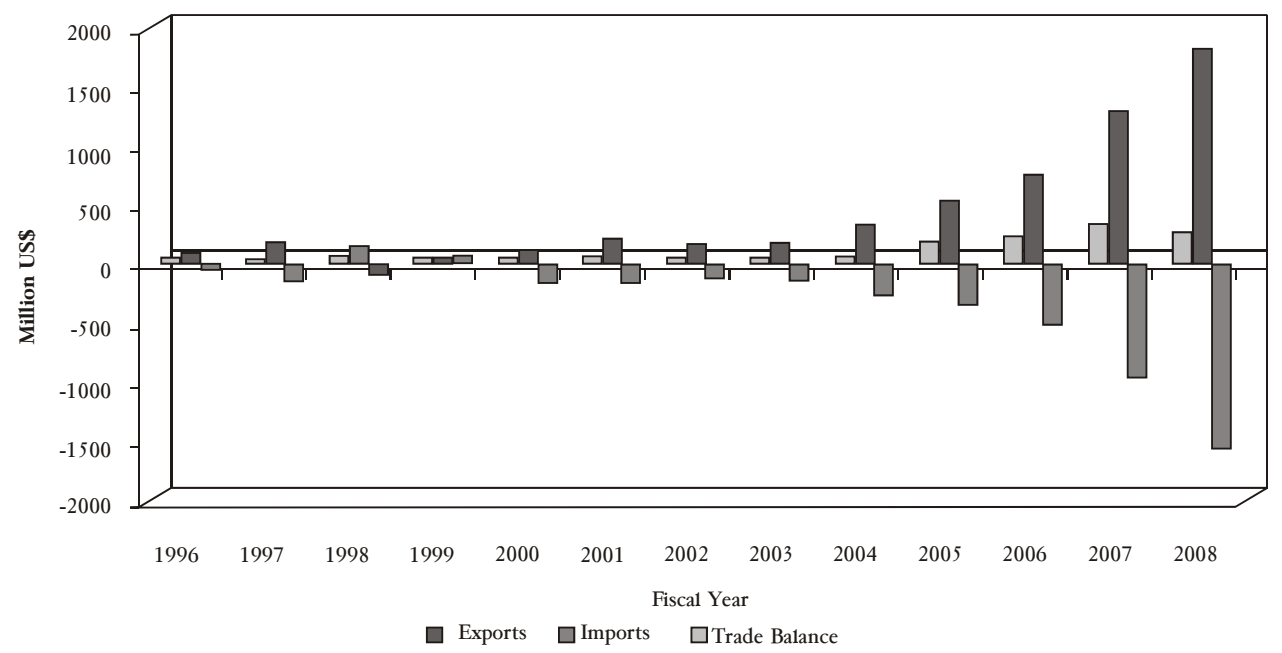

Notes: The trade balance is presented as Pakistan's exports to India minus its imports from India; the years refer to Pakistan's fiscal years (July 1 to June 30 ).

Source: Calculated from the average of Pakistan's and India's bilateral trade statistics.

Despite overall economic liberalization and globalization in both India and Pakistan, bilateral trade relations have been highly "managed." Official trade stood at US\$129 million in the fiscal year 1996 and reached an average of less than US\$250 million during fiscal years 2001-03. In comparison during this period, merchandise trade between India and the rest of the world increased from close to US\$70 billion to US\$101 billion. It is only after the two countries started the Composite Dialogue Process in January 2004 that there has there been a sizable increase in bilateral trade. Official trade between India and Pakistan reached US\$1.1 billion in 2005/06. According to estimates for $2004 / 05$, there was an additional US\$545 million in unofficial trade. ${ }^{12}$ Thus, total bilateral trade stood at US\$1.5 billion, or

\footnotetext{
${ }^{11}$ These figures are based on the average of the bilateral trade data reported by Pakistan and India. It must be noted that there are considerable discrepancies between the trade data of the two countries, partly because of differences in fiscal years. The consistent trend over the last 10 years is that Pakistan's trade data underreports exports to India compared to Pakistan's imports in the Indian data and over reports imports from India compared to what Indian data shows as exports to Pakistan. It would be useful to sort out these discrepancies as part of Pakistan-India trade discussions, particularly as the differences are large compared to normal discrepancies in bilateral trade statistics.

${ }^{12}$ Estimated by Khan (2007) et al. "Informal trade" here refers to bilateral trade that is not recorded as such in official statistics, because it moves through third countries (e.g., United Arab Emirates, Afghanistan, or Singapore), is smuggled, or is carried out by individuals carrying tradable items as personal baggage. These estimates are based on
} 
3.4 percent of Pakistan's total trade, in 2005/06. ${ }^{13}$ Between the fiscal years 2006 and 2008, Pakistan's trade with India increased by about US\$500 annually from US\$1.1 billion to close to US\$2 billion. If we assume that the volume of informal trade remains at more or less the same levels as in $2004 / 05$, then total bilateral trade stood at around US\$2.5-2.6 billion in 2007/08. While exports from Pakistan to India grew somewhat during the last 3 fiscal years, official imports increased at an average annual growth rate of $46 \%$, leading to a growing trade deficit with India (see Figure-7).

Another indication of the controlled nature of Pakistan-India trade is that bilateral trade had been limited to a few goods with almost no trade in services. The composition of Indian imports from Pakistan before during 2000-2004 was limited to about six commodity groups, which on average accounted for more than 80 percent of total exports (See Data Appendix Table-A3). These included edible vegetables and roots, sugar and confectionary, edible fruits, gum/resins and vegetable extracts (e.g. molasses), and products of the milling industry. Since 2004, after Pakistan and India began wide-ranging dialog on political and economic issues, the composition of Pakistani exports to India has become more diversified. In addition to traditional exports to India as mentioned above, mineral fuels and oils, vegetable plaiting materials, organic and inorganic chemicals, raw hides and skins, lead and articles made of lead, and salt/sulfur/cement have also been exported to India.

The composition of official exports from India to Pakistan is broader (see Data Appendix Table-A4), reflecting India's more diversified industrial base. Organic chemicals form the biggest share of Pakistani imports from India. Another major import to Pakistan from India has been ores/slag (mainly iron ore). During the last 4 years (2004/05 to 2007/08), imports of pharmaceutical products, mineral fuels/oils, manufactured filaments, plastic products, rubber products, leather, and copper and copper products have become important. Periodically, agricultural products (e.g., raw cotton, wheat, silk, and sugar) have accounted for one-time imports or exports to meet domestic shortages in either country.

The composition of informal trade between India and Pakistan is somewhat different. Estimates of informal trade range anywhere between US\$0.5-10 billion; our estimates for the fiscal year 2004/05 at US\$545

field research in border regions of Pakistan, in Dubai, and in major Pakistani urban markets.

${ }^{13}$ This includes an estimated value of informal trade between the two countries. We have assumed that the value of informal trade was $\$ 545$ million in 2005/06; the same value we estimated for 2004/05. 
million were closer to the lower range. Informal exports from Pakistan to India were valued at US\$10.4 million, consisting mostly of textiles and agricultural products. Informal imports from India were valued at $\$ 535$ million, including products such as textiles, spices, medicines, machinery, and tires. Much of the informal trade takes place in goods that are either not on Pakistan's positive list (e.g., pharmaceuticals, cosmetics, and jewelry), have high tariffs in Pakistan (e.g., betel leaves, tractor tires), or face high tariffs through specific taxes in India (e.g., Pakistani textile products). The major routes used for informal trade go through Dubai, Iran, and Afghanistan. These informal trade routes are often over difficult terrain and use different modes of transportation. In addition, informal trade also takes place across the extended land borders between the two countries. Thus, a more liberalized and open trade regime between India and Pakistan would allow informal trade to become legalized and both governments would be able to earn tariff revenues from the expanded volume of trade.

\section{Bilateral Trade Potential}

\section{Trade in Goods}

Baroncelli (2007) has used a gravity model to show that potential trade, including formal and informal trade, could have amounted to $\$ 3.2$ billion in the year 2000-which is over 400 percent higher than actual flows at the time. This would have come from enhanced cooperation in security and trade policies. Pakistan and India could potentially increase their bilateral trade by another 79 percent by entering a regional trade arrangement/agreements (RTA) such as SAFTA. The State Bank of Pakistan (2006) has estimated a trade potential of $\$ 5.2$ billion for the fiscal year 2004 using the revealed comparative advantage methodology. ${ }^{14}$ The State Bank of Pakistan report suggests considerable potential for Pakistan to export a range of agricultural and manufactured products including textiles, chemicals, and even machinery; and for India to expand its exports in a range of products, with expected savings of US\$400-900 million due to lower transportation costs. Batra (2004) has used a gravity model to estimate a potential trade volume of $\$ 6.6$ billion annually. The FICCI (2003) has estimated a trade potential of around \$6-8 billion. The Karachi Chamber of Commerce and Industry predicts that trade could be as high as $\$ 5-10$ billion. We find that estimates of potential bilateral annual trade range between $\$ 3$ billion and 10

\footnotetext{
${ }^{14}$ Revealed comparative advantage methodology is an indicator of a country's intrinsic comparative advantage. In its original form it was a measure of relative export performance by a country or industry, defined as a country's share of world exports of a good divided by its share of total world exports. It has subsequently been used in a broader sense to look at both imports and exports.
} 
billion. Thus, at best, these two large South Asian countries currently exploit only two thirds to one quarter of the potential that exists in bilateral trade. ${ }^{15}$

In addition, there is sizeable potential for intra-industry trade and exchange of technology and skills between India and Pakistan. There are indications of significant potential for trade in a number of sectors. For instance, Pakistan and India already trade in agriculture goods to meet local shortages in bulk items like wheat, sugar, raw cotton, and other agricultural products in the event of crop failures. ${ }^{16}$ In textiles, intra-industry trade already takes place in both formal and informal ways. Pakistan has a comparative advantage in both pure cotton-based fabrics and short-staple fiber yarn/fabric. India has a distinct advantage in long-staple fibers, polyester fibers, and polyester-based fabrics. In engineering, we found ${ }^{17}$ that Pakistan had an edge in the export of ceiling and pedestal fans, while India could potentially become a dominant player in the Pakistani market for standard workhorse type bicycles. Another area is trade in pharmaceuticals. Recent news reports indicate that Pakistani pharmaceutical companies are increasingly trying to move away from China and looking toward India as a source of supply for machinery and raw materials, especially for herbal, Unani, and homeopathic medicines.

\section{Trade in Services}

Furthermore, there could be great potential for intra-firm trade in the services sectors, particularly in health, information technology (IT), tourism, and entertainment. In July 2003, young Noor Fatima made headlines as she travelled by bus to India and underwent successful heart surgery at the Narayana Hrudayalaya hospital in Bangalore. Subsequently, many other Pakistanis have been treated in India, which is becoming an important international center for the healthcare industry. IT is another industry that has done extremely well in India over the last decade and a half. There is tremendous scope for exploring and developing business and trade ties with India's IT providers by Pakistani counterparts. There have been visits, exchanges, and personal collaboration among musicians and film stars across the border. Easing the visa regime and labor mobility would go a long way in developing stronger ties between the two countries in the media and entertainment industry. We mention various anecdotal examples in these areas because there is very little analytical work on the possibility

\footnotetext{
${ }^{15}$ Using the basis of US\$2 billion in official trade figures for 2007/08.

16 These traded agricultural goods have from time to time included potatoes, ginger, onions, and garlic.

${ }^{17}$ We refer here to the work in The Challenges and Potential of Pakistan-India Trade.
} 
for developing bilateral trade in the services sectors. This is an area that needs further research in order to fully understand its potential size and implications for both countries.

\section{Impact on Regional/Local Economies}

In the most optimistic scenario, we foresee a future for PakistanIndia trade that replicates the pre-1947 trade pattern but in a new setting. Lahore could become the hub for trade with smaller Indian towns like Amritsar, Jullandar, Firozpur, and Ambala, as existed before Partition. These and other smaller towns in the Indian and Pakistani Punjab (e.g., Gujrat, Gujranwala, Sialkot, Wazirabad, Faisalabad) could benefit from intra-industry trade in agriculture and manufactured goods. Peshawar used to be an entry port for the movement of goods from the mainland Indian Subcontinent northwest to Afghanistan and beyond. To some extent, Peshawar and its neighboring towns are business centers for unofficial trade between India and Pakistan. If Pakistan allows transit facilities over land to India for its trade with Afghanistan, then Peshawar and many towns in the Northwest Frontier Province could gain substantially. Quetta, Gwadar, and other towns in Balochistan could gain from expanded trade with India, particularly if India were to use land routes over Pakistan and the new Gwadar port facilities to trade with the Gulf, Afghanistan, and Central Asia. Karachi and towns in Sindh could be the beneficiaries of normal trade relations with India because of sea trade via the Karachi port and cross-border trade between Sindh and the western and central Indian provinces. Normal trade relations with India and resolution of the Kashmir dispute would also lead to large benefits for people living in Indian- and Pakistan-occupied Kashmir. The devastating earthquake of October 2005 in Pakistan-occupied Kashmir made the two countries open up the disputed Kashmir border for the flow of relief goods, saving hundreds of lives. If the natural trade corridors that existed in this area were to be restored, as the initial agreement to open the Srinagar-Muzaffarabad and Poonch-Rawalakot borders indicated, then the potential peace dividends could be enormous.

At best, the above discussion presents partial estimates of the gains from liberalized bilateral trade. It is difficult to predict with any certainty the volume of trade creation following trade liberalization, since the dynamics of reintegrating the two 1arge economies after a hiatus of 60 years would be complex and cannot be easily modeled. However, we can safely say that geography, the socioeconomic situation, and the recent rapid increase in consumption demand in Pakistan and India suggest that gains are likely to be multidimensional and substantial. 


\section{Bilateral Trade Issues}

\section{Political Relations}

The political environment between Pakistan and India continues to be marred by mutual suspicion. Despite many efforts by civil society and to some extent by both governments, the mindset of viewing the "other" as the enemy still prevails. Of course, there are good reasons for these views to be perpetuated: the core Kashmir conflict has yet to be resolved, the 1965 war, the 1971 dismemberment of the country, and more recently the Kargil conflict refresh the "enemy" status from time to time. Since 2004, Pakistan and India started the Composite Dialogue Process (CDP), which emphasizes an eight-point agenda ${ }^{18}$ covering a range of defense, political, and economic issues. In its early phase, almost-monthly announcements on measures agreed to by Pakistan and India generated confidence that the baggage of the past might possibly be buried.

On the economic front, the two governments have tackled a broad agenda, ranging from improving trade logistics, easing visa restrictions, reducing nontariff barriers, facilitating trade via sea, land, and rail routes, to opening up banking sectors. For instance, the rail service between Khokrapar and Monabao in the Sindh-Rajasthan border was revived after having been closed since 1965. New bus services link the two Kashmirs between Srinagar and Muzaffarabad, as well as places of religious significance between LahoreAmritsar and Amritsar-Nankana Sahib. During the third round of the CDP discussions in March 2006, both countries agreed to discuss a new shipping protocol, the deregulation of air services, joint registration of basmati rice, an increase in the size of Pakistan's positive list, proposals for IT-related medical services and export insurance, and to work on a memorandum of understanding for cooperation in capital markets.

This process moved forward in subsequent rounds. The revised India-Pakistan shipping protocol that was signed in December 2006 removed restrictions (in place since 1975) allowing the lifting of thirdcountry cargo by Indian and Pakistani vessels from each other's ports. It also lifted the restriction that cargo destined for the other country could be carried only by an Indian or Pakistani vesse1. Pakistan and India decided to open bank branches of Pakistani-scheduled banks in India and vice

\footnotetext{
${ }^{18}$ The India-Pakistan Composite Dialogue process began in January 2004 after a meeting of between Indian Prime Minister Atal Bihari Vajpayee and Pakistani President Pervez Musharraf. The eight-point agenda covers peace and security, Jammu and Kashmir, Siachen, Sir Creek, Wullar Barrage, terrorism and drug trafficking, economic and commercial cooperation, and the promotion of friendly exchanges in various fields.
} 
versa. For the first time in decades, Pakistani cinemas started showing Indian films and the epic film "Mughal-e-Azam" was well received. In July 2007, the University of Mumbai and University of Sindh signed a memorandum of understanding for exchange of faculty, scholars, and students. In October 2007 the first overland truck route between India and Pakistan was opened at the Wagah border crossing. In April 2008, "In the Name of God" became the first Pakistani film in four decades to be approved for release in Indian theatres, and, a month later, Pakistan's rock band, Junoon, was allowed by the Indian government to perform at Srinagar at the biggest musical event in decades. In the same month, India signed a framework agreement with Turkmenistan, Afghanistan, and Pakistan on a $\$ 7.6$ billion gas pipeline project that is expected to supply 3.2 billion cubic feet per day (90 MMSCMD) starting in 2015 with Pakistan and India agreeing to share equally in the gas volume. In September 2008, President Zardari and Prime Minister Manmohan Singh formally announced the opening of several trade routes between the two countries. The Wagah-Atari road link and the Khokrapar-Munnabao rail link were to be opened to trade, as well as the cross-LoC SrinagarMuzaffarabad and Poonch-Rawalakot roads. Trade across the Line of Control commenced as the first trucks crossed the LoC on October 21, $2008 .^{19}$ Although skeptics on both sides of the border felt that the CDP was not making a real impact in resolving deep-seated mistrust, these measures did have an impact on opening up the dialogue and leading to more transparency and confidence building measures.

Episodic incidents of terrorism in India or Pakistan have led to each country blaming the other and to periodic setbacks in warming relations. These trends existed before the beginning of the CDP in January 2004 and have continued since. For instance, the explosion in Delhi markets in October 2005, the bombs in Mumbai train stations in July 2006, and the bomb explosions on the Samjhauta express in February 2007, were all blamed on Pakistan-based terrorists by India. Pakistan too has blamed Indian RAW agents for the insurgency in Balochistan and terrorist attacks in Pakistani cities and towns, and for attacks on its diplomatic mission in Afghanistan. But the latest terrorist attacks in Mumbai in November 2008 have put a hold on the CDP, and this is likely to have a more lasting impact. The recent attack on the Sri Lankan cricket team in Lahore in March 2009, the finger-pointing toward Indian RAW agents as possible culprits, and ensuing statements from India have not helped matters. Unless the CDP is restarted soon, political relations in general and trade in particular could be another casualty of the Mumbai terror attacks.

${ }^{19}$ Initially trade on this route was limited to 21 items and two days each week. 


\section{Most Favored Nation (MFN) Status}

Although India granted Pakistan MFN status in 1995/96, Pakistan has not yet reciprocated this move. From India's perspective, the issue is a sticking point in trade and political discussions. Pakistan's strategy has been to avoid full MFN status but to steadily increase the size of the positive list of importable goods from India. ${ }^{20}$ The list has expanded from 40 items in 1983 to 687 items in 2004/05, to 770 items in 2005/06 and to 1,075 items as part of the SAFTA process. Despite these additions, the positive list remains restrictive and unclear.

As part of improving relations, the positive list of importable goods from India was further increased to 1,082 items in the $2007 / 08$ Trade Policy and to more than 1,983 items in 2008/09. The 2008/09 Trade Policy was visibly geared to enhancing trade with India. It announced that the import of diesel and fuel oil, import of academic, scientific and professional books, and import of stainless steel and cotton yarn via trucks using the Wagah border in addition to their import by other modes, would be allowed. Pakistan even allowed the possibility of foreign direct investment (FDI) from India in the manufacture of CNG buses. ${ }^{21}$ This was a good beginning and indicated the possibility of not just trade but investment flows between the two countries. The Trade Policy 2008-09 also allowed imports of goods under a DTRE scheme from India even if these goods were not among the positive list of importable items. The latter provision has been part of earlier trade policies as well, which makes it difficult to assess the extent of allowable number of items from India. Our estimates for 2005/06 showed the positive list included approximately 45-50 percent of Pakistan's total importable goods, but in its current form, the list is not very transparent. ${ }^{22}$

Thus, while Pakistan continues to deny MFN status to India, de facto the situation resembles MFN status because far more is importable

\footnotetext{
${ }^{20}$ Under a "positive list" approach, only those items on the list may be imported, and any item not on the list is banned. In contrast, items on a "negative list" are banned, and any item that is not on the list may be imported.

${ }^{21}$ The 2008-09 Trade Policy allowed for the import of 10 sample buses via the land route from every interested Indian manufacturer who was willing to make a firm commitment to start manufacturing in Pakistan.

${ }^{22}$ In 2005/06, the 773 items corresponded to around 1,650 tariff lines at the eight-digit level of the harmonized system (HS) codes. With an addition of 320 items in November 2006, the list covered around 2,000 tariff lines at the eight-digit HS code level. A number of aggregated categories are also included that cover a large number of tariff lines, such as laboratory equipment, pharmaceuticals, and HIV/AIDS drugs. In addition, a few regulations cover additional items that are allowed to be exported under bonded warehouses, export houses, and duty neutralization schemes.
} 
with the growing size of the positive list, DTRE provisions within the trade policies, and unofficial imports coming from India. In this scenario, it makes very little sense to continue holding off granting MFN status to India.

Islamabad's policy of gradually expanding the positive list seems to be paying off. Official trade between India and Pakistan stood at less than $\$ 250$ million during fiscal years 2001-03, which increased to US\$ 849 million in $2004 / 05$. Official trade reached a record of $\$ 1.1$ billion in $2005 / 06$ and close to US\$ 2 billion in 2007/08. Projecting from these trends, we would expect official trade between India and Pakistan to be close to US\$ 2.7-2.8 billion with the latest expansion of the positive list in 2008/09 (Figure-8).

Figure-8: Expansion of Positive List and Positive Trade Outcomes

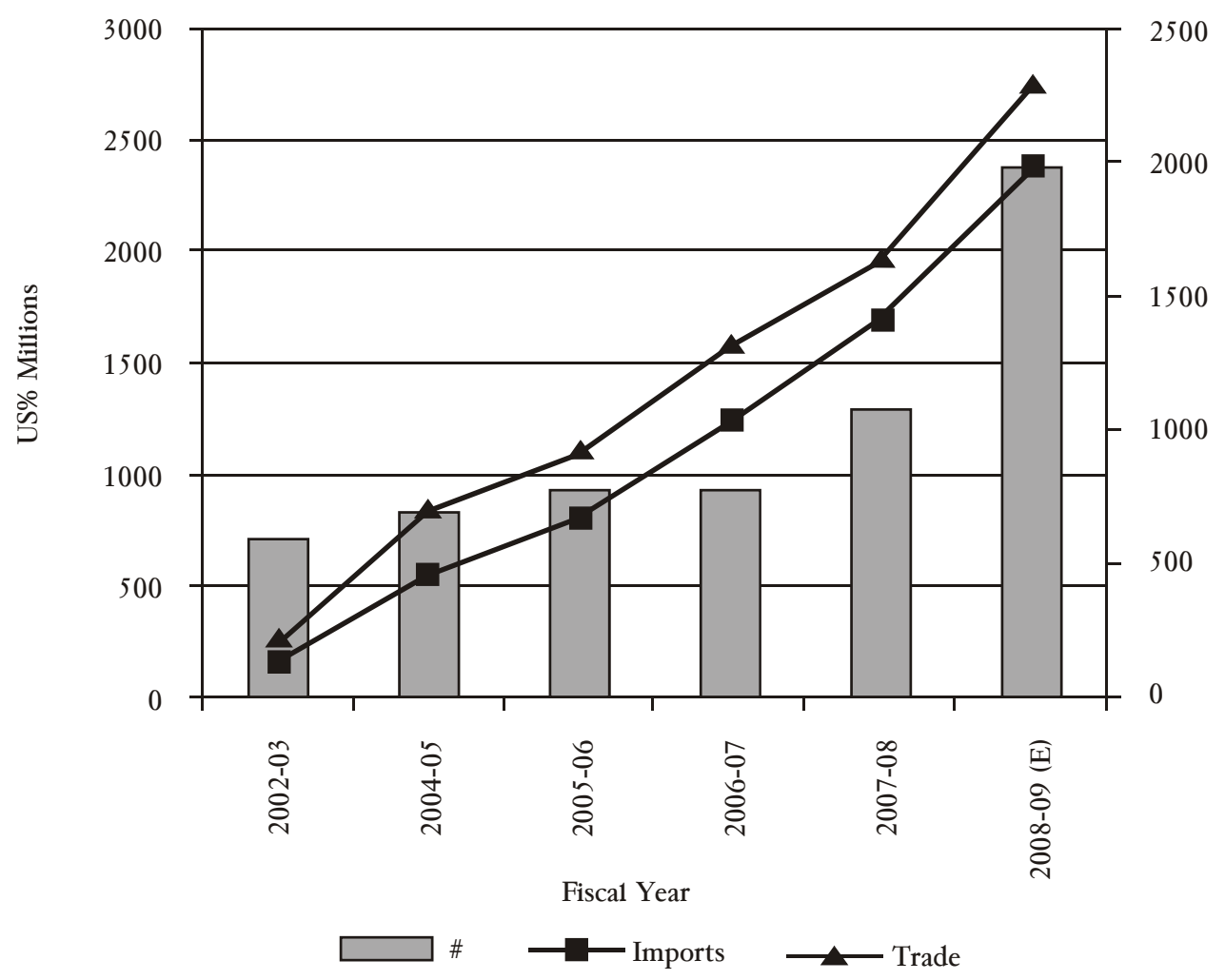

Source: Pakistan Import Policy Orders, various years, and Pakistan's Trade Policy.

\section{Barriers to Trade}

Both India and Pakistan still use tariff and nontariff barriers to protect their domestic producers even after reforms have led to overall economic liberalization. India is ranked $115^{\text {th }}$ out of 125 countries on the 
World Bank's latest (2006-08) Trade (MFN) Tariff Restrictiveness Index (TTRI) and Pakistan stands at $102^{\text {nd }}$ place. India's trade regime is far more restrictive than other large emerging economies like Brazil, China, Mexico, and Russia or compared to neighboring countries in South Asia. India's ranking on the Ease of Doing Business indicators is also quite low with the latest ranking for 2006-08 at 122th out of 178 countries compared to Pakistan's rank at $77^{\text {th }}$ place.

Table-1: Tariff Restrictiveness in India and Pakistan

\begin{tabular}{|c|c|c|c|c|c|c|c|c|c|c|}
\hline \multirow{2}{*}{$\begin{array}{l} \\
\text { Country/ } \\
\text { Group } \\
\end{array}$} & \multirow[b]{2}{*}{ Year } & \multicolumn{3}{|c|}{$\begin{array}{l}\text { Average Tariff Rate } \\
\text { (unweighted in \%)/a }\end{array}$} & \multicolumn{3}{|c|}{$\begin{array}{l}\text { Bound Tariff Rate } \\
\text { (unweighted in \%) }\end{array}$} & \multicolumn{3}{|c|}{ Binding Coverage } \\
\hline & & $\begin{array}{c}\text { All } \\
\text { Goods }\end{array}$ & $\begin{array}{c}\text { Agricu } \\
\text { lture }\end{array}$ & $\begin{array}{c}\text { Manufa } \\
\text { ctures }\end{array}$ & $\begin{array}{c}\text { All } \\
\text { Goods }\end{array}$ & $\begin{array}{c}\text { Agricul } \\
\text { ture }\end{array}$ & $\begin{array}{c}\text { Manufa } \\
\text { ctures }\end{array}$ & $\begin{array}{c}\text { All } \\
\text { Goods }\end{array}$ & $\begin{array}{c}\text { Agricul } \\
\text { ture }\end{array}$ & $\begin{array}{r}\text { Manufa } \\
\text { ctures }\end{array}$ \\
\hline India & 2007 & 14.0 & 39.1 & 12.5 & 49.6 & 113.3 & 34.4 & 73.8 & 100.0 & 69.8 \\
\hline Pakistan & 2007 & 14.5 & 16.6 & 14.4 & 52.2 & 96.8 & 35.4 & 44.7 & 92.5 & 37.4 \\
\hline \multicolumn{11}{|c|}{ Simple Average } \\
\hline \multicolumn{2}{|c|}{$\begin{array}{l}\text { Developing } \\
\text { countries } \\
(125)\end{array}$} & 10.5 & 15.0 & 10.1 & 45.5 & 62.3 & 34.0 & 74.4 & 98.8 & 70.7 \\
\hline \multicolumn{2}{|c|}{$\begin{array}{l}\text { Low Income } \\
\text { (46) }\end{array}$} & 12.1 & 16.6 & 11.8 & 60.7 & 75.4 & 38.5 & 52.1 & 97.6 & 45.1 \\
\hline \multicolumn{2}{|c|}{$\begin{array}{l}\text { Middle Income } \\
\text { (79) }\end{array}$} & 9.6 & 14.1 & 9.2 & 36.1 & 54.2 & 31.2 & 88.3 & 99.5 & 86.6 \\
\hline \multicolumn{2}{|c|}{$\begin{array}{l}\text { High Income } \\
\text { Non-OECDs } \\
(14)\end{array}$} & 6.5 & 6.0 & 6.5 & 24.6 & 36.3 & 22.5 & 82.1 & 99.7 & 79.4 \\
\hline \multicolumn{2}{|c|}{$\begin{array}{l}\text { High Income } \\
\text { OECDs (10) }\end{array}$} & 3.6 & 11.0 & 2.8 & 6.8 & 13.0 & 6.0 & 98.6 & 99.6 & 98.4 \\
\hline
\end{tabular}

Source: The World Bank, Data on Trade and Import Barriers, http://econ.worldbank.org/WBSITE/EXTERNAL/EXZTDEC/EXTRESEARCH/0,,con tent/MDK21051044-pagePK:64214825-piPK64214943-theSitePK 469382.00.html

India's MFN applied average tariff rate at 14.5 percent (in 2007) is much lower than tariff rates a decade ago. However, the applied tariff rate for agriculture exports at 39 percent in 2007 is one of the highest in the world (see Table-1). This is a major barrier for Pakistani exporters of agricultural products in terms of expanding trade with India. Although overall unweighted tariff rates for manufactured goods are lower in India than in Pakistan, India's tariff regime is more complicated than what these indicators suggest. In a number of sectors, specific tariffs and regulatory duties override statutory 
MFN tariff rates. For instance, potential textiles exports from Pakistan are subject to specific duties which can as high as $50-100 \%$ in equivalent tariff rates. Tariff peaks in India are prevalent in the agricultural, automobiles, and textiles and garments sectors. Particularly important are the barriers that textile and garments exporters from Pakistan face.

One of the major nontariff barriers (NTB) used by Pakistan vis-à-vis India is the positive list of importable goods. This barrier has been eroded considerably in recent years as discussed above. According to Taneja's (2007) survey of Indian exporters doing business with Pakistan, very few other NTBs in Pakistan restrict trade. Meanwhile, India uses a barrage of NTBs to constrain trade with the rest of the world. According to the World Bank's frequency coverage of NTBs-a measure of NTB restrictiveness-India's ratio of 51 percent $^{23}$ (in 1997) is one of the highest in the world. In comparison, Pakistan's ratio of the frequency coverage of NTBs was much lower at 29 percent (1998). ${ }^{24}$ India is among the second-largest user of trade defense laws, such as anti-dumping measures, in the world. It also applies stringent domestic standards to restrict trade, whereas in Pakistan normal international standards are applied to most traded goods.

There are numerous other barriers to trade in terms of poor trade logistics and inadequate infrastructure. A key impediment to trade is the restrictive visa regime that limits visas to three cities per trip, does not provide multiple-entry visas, stipulates that entry and exit be made via the same port of entry, and requires (in most instances) reporting to the police in the cities visited both when arriving and departing. At present, infrastructure and border facilities are grossly inadequate for handling trade volume growth. Warehousing and storage facilities on border crossings are equally inadequate. Manual data entry and antiquated customs procedures lead to delays in the movement of cargo. Additionally, the regulations that currently guide cross-border bilateral trade are geared to curbing-not promoting-trade. For instance, the railway wagons used for trading goods on the Samjhota express are grossly inadequate. The rail service is not regular or reliable. Trucks are only allowed between 8:00 and 16:00 on the land route and rail traffic is limited to 10:00-17:00 hours. Containerized cargo is not permitted on land routes, which results in higher rates of damage and pilferage. The agreement on trade across the LoC in Kashmir is restricted to $1 \mathrm{MT}$ trucks and 21 items; reports indicate that even these take a long time to cross the border because of overly cautious border checking.

\footnotetext{
${ }^{23}$ Imported weighted average ratio. The unweighted average ration for India was $43 \%$.

${ }^{24}$ From: http://siteresources.worldbank.org/INTRES/Resources/OTRIindices.pdf
} 
The use of agricultural subsidies is widespread in India. Similarly, India protects its small-scale producers with protective regulations and also provides implicit subsidies to exporters. Subsidies in general have been phased out in Pakistan as part of economic reforms over time. All these factors add to the apprehension of Pakistani businesses and limit their access to an even playing field in the Indian market. These concerns, together with India's proclivity for using tariff and nontariff barriers, continued high subsidies to farmers and small domestic enterprises, have merit and will need to be addressed as part of the safeguards while negotiating liberalized trade. However, it would not be fruitful to make the redress of these barriers a precondition for liberalizing bilateral trade.

\section{Regional Trade/Economic Integration:}

As a result of long-drawn out political conflict and inward looking policies in the 1960s, 1970s, and much of the 1980s, economic integration in South Asia has been stymied, and by all accounts it is one of the least integrated regions in the world. Both India and Pakistan have hesitated to forge economic ties with countries in the region or with neighboring regions. In the 1960s and 1970s, Pakistan was a member of the Regional Cooperation for Development (RCD) and Economic Cooperation Organization (ECO). India was not part of any major trade or regional arrangements.

Looking at the success of regional arrangements in Southeast Asia and North America, and partly due to the disenchantment with the multilateral trade regime (e.g., the Doha Development Round), a number of countries are now looking to preferential trade or regional trade agreements (PTAs or RTAs) to enhance trade. Both Pakistan and India have embraced this new doctrine. India has entered a number of bilateral and regional arrangements in recent years "demonstrating the enthusiasm of a recent convert." India has implemented bilateral agreements with Sri Lanka, Singapore, Thailand, Malaysia, Indonesia, Chile, Mauritius, and Afghanistan, and is in the process of discussing similar agreements with Korea, New Zealand, Australia, Japan, and China. Besides SAFTA, India is now involved in the Association of Southeast Asian Nations (ASEAN), South Africa Customs Union (SACU), Mercosur, Bay of Bengal Initiative for Multi-Sectoral Technical and Economic Cooperation (BIMSTEC), Asia Pacific Trade Agreement (APTA), and the Gulf Cooperation Council (GCC). ${ }^{26}$ In November 2005 a joint US-India trade policy forum for discussing trade and

\footnotetext{
${ }^{25}$ Quoted from the editorial of Economic and Political Weekly, January 7, 2006.

26 See http://www.commerce.nic.in/trade/international_ta_current.asp for details on India’s current RTAs status.
} 
investment issues was begun. India and the European Union (EU) initiated the process of forging an EU-India trade and investment agreement in June 2007. Meanwhile, Pakistan has signed a bilateral trade agreement Sri Lanka that was implemented in 2005, and an FTA with Malaysia in 2007. Pakistan signed an FTA with China in November 2006, which merged the previous Early Harvest Agreement between the two countries. ${ }^{27}$

This new zeal for bilateral and regional trade arrangements implies that arrangements like SAFTA, which aspired to create the largest free trade area affecting 1.4 billion people in South Asia, may have become redundant. All seven original member states of the South Asian Association for Regional Cooperation (SAARC) ${ }^{28}$ ratified the agreement, which came into force on January 1, 2006. SAFTA aimed to boost trade among member countries by reducing and eventually eliminating tariff barriers, facilitating the cross-border movement of goods, promoting fair competition in the region, and creating an effective framework for regional cooperation. On the negative side, SAFTA has a comparatively longer timeframe for implementation, a highly restrictive list of sensitive goods, and strict rules of origin. Although SAFTA provides a framework to facilitate investments, improve the harmonization of standards, and facilitate customs and transit, its success depends on how it is actually implemented, and in particular how India and Pakistan work together in making SAFTA an effective means of enhancing regional integration. There have been a few setbacks because of disputes between the two largest SAARC economies-Pakistan and India. ${ }^{29}$ These developments and the proliferation of PTAs and RTAs by India and Pakistan suggest that the promise of SAFTA, as it was originally laid out, has been significantly eroded.

\footnotetext{
${ }^{27}$ For details see: http://www.commerce.gov.pk/tradeagreements.asp.

${ }^{28}$ These include India, Pakistan, and Sri Lanka as non-least-developed countries (nonLDCs), and Bangladesh, Maldives, Nepal, and Bhutan as least-developed countries (LDCs). Recently, Afghanistan was accepted as a new member of SAARC and an LDC member of SAFTA. China, Japan, Korea, Iran, the EU, and the US have been granted observer status in SAARC.

${ }^{29}$ The major dispute between Pakistan and India came up during the SAARC Ministerial Meeting in February 2007. Pakistan offered tariff concessions to India only on its "positive" list of importable goods from India. India termed this move a NTB and contrary to the SAFTA agreement, which stipulates that tariff concessions be given on all goods except those goods on the "sensitive" list that are to be identified by each country for least-developed countries (LDCs) and non-LDCs. At that time India hinted that it might review, and, in the worse case, possibly revoke the tariff concessions given to Pakistan under SAFTA.
} 


\section{Conclusions and Recommendations}

Analysis of the potential for Pakistan-India trade and the issues/constraints related to trade expansion lead us to making the following recommendations.

1. Restart the CDP. In order to realize potentially large static and dynamic peace dividends, ${ }^{30}$ both governments need to revive the $\mathrm{CDP}$ as soon as possible. Considerable gains have been made by this process since it started. This momentum should not be sacrificed at the hands of terrorists. This was also one of urgent appeals of the UN Secretary General Ban Ki-Moon soon after the Mumbai attacks.

2. Pakistan should consider granting MFN status to India. This would provide political mileage for Pakistan, as India has been able to deflect pressure to liberalize trade with Pakistan by pointing to the absence of formal MFN treatment. After granting this privilege, Pakistan would be able to raise more substantive issues, notably Indian NTBs, subsidies, and protective tariffs. Pakistan has already granted something close to de facto MFN status to India if we look at the composition of both formal and informal trade. Thus, this move could lead to substantial political gains. In sum, holding back the granting of MFN status to India is harming Pakistan in international fora and in its bilateral negotiations on economic and political issues.

3. Continue to reduce the impediments to bilateral trade. Building on the foundations of the dialogue process, there has to be free movement of goods, capital, and people-businessmen, investors, students, media persons, and skilled workers. Both India and Pakistan need to tackle their restrictive visa regimes. A number of issues related to trade infrastructure and logistics can be done unilaterally such as the initiation of Electronic Data Interchange (EDI), more efficient customs processing at land border crossings, setting up or upgrading and warehousing, testing and security facilities, and setting up bank branches to ease financial transactions on both sides of the border. Certain other measures have to be taken bilaterally, such as permitting containerized cargo on land routes, increasing the frequency of air, rail and bus services,

\footnotetext{
${ }^{30}$ Static refers to peace dividends at a point in time, say now. Dynamic peace dividends would be the gains from better trade and economic relations over a period of time, say over the next 5-10 years.
} 
developing harmonized systems of transit and trade, and investing in trade-supporting infrastructure. Pakistan would also have to negotiate with India to create a level playing field in areas where the Indian government provides subsidies, concessions, or special incentives to certain industries. These issues would have to be taken up for negotiations and resolved by the two governments.

4. Study the possibility of an FTA with India. Given India's rather complicated trade regime and keenness to seek FTA/RTAs, perhaps it is time to consider the possibility of a bilateral FTA with India. This idea may sound inappropriate in the current circumstances while political tensions are high and Pakistan has yet to grant MFN status to India, but the idea has some merit. The promise of regional integration within South Asia under SAFTA is almost dead. Pakistan's largest trading partners, the EU and US, have begun discussions with India for possible ITAs, with the EU-India ITA expected be negotiated in coming months. The EU, being Pakistan's largest export market and among the biggest sources of FDI, the impact of the potential EU-India ITA on Pakistan's trade and investment could be devastating. For example, the textile and clothing sector which accounts for $77 \%$ of Pakistan's exports to the EU could be seriously affected if lower tariffs are applicable on competing Indian products in the European market. Pakistan's fledgling IT services exports could encounter difficulties in entering the EU and US markets if Indian IT exports capture most of these markets under ITAs. Similarly, Pakistan's already lower FDI flows compared to India could further slow down if many EU and US companies prefer to invest in India to take advantage of future preferential investment arrangements. Unless Pakistan is engaged in a serious dialogue on trade issues with India, it will have little success in raising issues related to high tariffs, specific duties, NTBs, agricultural and export subsidies that impact Pakistan-India trade, nor can it meaningfully raise Pakistani concerns related to other FTAs/PTAs that India may be negotiating. Within the framework of Pakistan-India FTA discussions, Pakistan could strategically give in on long-standing Indian demands of granting MFN status (in fact, go the extra mile and grant preferential status) and providing land transit routes to Afghanistan and in return seek concessions on tariffs and other barriers that limit access to the Indian markets. Even if this idea is not currently feasible, a sound assessment of the potential for the trade creating and diverting effects and strategic impact on trade and investment under a possible Pakistan-India FTA could be studied at this time. 
Appendix

Table-A1: India's Trade with Pakistan and the Rest of the World (Value in \$ Million)

2000-01 2001-02 $2002-03 \quad 2003-04 \quad 2004-05 \quad 2005-06 \quad 2006-07 \quad 2007-08$

\begin{tabular}{|c|c|c|c|c|c|c|c|c|}
\hline \multicolumn{9}{|c|}{ Exports } \\
\hline $\begin{array}{l}\text { Exports to } \\
\text { Pakistan }\end{array}$ & 186.8 & 144.0 & 206.2 & 286.9 & 521.1 & 689.2 & 1348.6 & 1945.1 \\
\hline$\%$ growth & & -22.9 & 43.2 & 39.2 & 81.6 & 32.3 & 95.7 & 44.2 \\
\hline $\begin{array}{l}\text { India's total } \\
\text { Exports }\end{array}$ & $44,560.3$ & $43,826.7$ & $52,719.4$ & $63,843.0$ & $83,535.9$ & $103,090.5$ & $126,262.7$ & $162,983.9$ \\
\hline$\%$ growth & 21.0 & -1.7 & 20.3 & 21.1 & 30.8 & 23.4 & 22.48 & 29.1 \\
\hline $\begin{array}{l}\text { \% share of } \\
\text { Pakistan }\end{array}$ & 0.42 & 0.33 & 0.39 & 0.45 & 0.62 & 0.67 & 1.07 & 1.19 \\
\hline \multicolumn{9}{|c|}{ Imports } \\
\hline $\begin{array}{l}\text { Imports from } \\
\text { Pakistan }\end{array}$ & 64.0 & 64.8 & 44.9 & 57.7 & 95.0 & 179.6 & 323.0 & 287.9 \\
\hline$\%$ growth & & 1.1 & -30.7 & 28.5 & 64.5 & 89.1 & 79.89 & -10.8 \\
\hline $\begin{array}{l}\text { India's total } \\
\text { Imports }\end{array}$ & $50,536.5$ & $51,413.3$ & $61,412.1$ & $78,149.6$ & $\begin{array}{c}111,517 \\
4\end{array}$ & $149,165.7$ & $185,604.0$ & $251,562.0$ \\
\hline$\%$ growth & 1.7 & 1.7 & 19.5 & 27.3 & 39.7 & 33.8 & 24.4 & 35.5 \\
\hline $\begin{array}{l}\% \text { share of } \\
\text { Pakistan }\end{array}$ & 0.13 & 0.13 & 0.07 & 0.07 & 0.08 & 0.12 & 0.17 & 0.11 \\
\hline \multicolumn{9}{|c|}{ Total Trade } \\
\hline $\begin{array}{l}\text { Trade with } \\
\text { Pakistan }\end{array}$ & 250.9 & 208.8 & 251.0 & 344.6 & 616.0 & 868.8 & $1,671.5$ & $2,233.0$ \\
\hline$\%$ growth & & -16.8 & 20.2 & 37.3 & 78.8 & 41.0 & 92.4 & 33.6 \\
\hline $\begin{array}{l}\text { India's total } \\
\text { Trade }\end{array}$ & $95,096.8$ & $95,240.0$ & $\begin{array}{c}114,131 \\
6\end{array}$ & $\begin{array}{c}141,992 \\
6\end{array}$ & $\begin{array}{c}195,053 \\
4\end{array}$ & $252,256.3$ & $311,866.8$ & $414,546.2$ \\
\hline$\%$ growth & & 0.2 & 19.8 & 24.4 & 37.4 & 29.3 & 23.6 & 32.9 \\
\hline $\begin{array}{l}\% \text { share of } \\
\text { Pakistan }\end{array}$ & 0.26 & 0.22 & 0.22 & 0.24 & 0.32 & 0.34 & 0.5 & 0.54 \\
\hline $\begin{array}{l}\text { Exchange } \\
\text { rate }\end{array}$ & 45.68 & 47.69 & 48.39 & 45.95 & 44.93 & 44.27 & 45.28 & 40.24 \\
\hline
\end{tabular}

Source: Department of Commerce, Government of India. Htt://commerce.nic.in

Note: Does not include import of crude oil and petroleum products from Pakistan 
Table-A2: Pakistan's Trade with India and the Rest of the World (Value in \$ Million)

2000-01 2001-02 $2002-03 \quad 2003-04 \quad 2004-05 \quad 2005-06 \quad 2006-07 \quad 2007-08$

\begin{tabular}{|c|c|c|c|c|c|c|c|c|}
\hline \multicolumn{9}{|c|}{ Exports } \\
\hline $\begin{array}{l}\text { Exports to } \\
\text { India }\end{array}$ & 55.4 & 49.2 & 70.7 & 93.7 & 288.1 & 293.3 & 342.9 & 254.8 \\
\hline$\%$ growth & & -11.2 & 43.7 & 32.5 & 207.5 & 1.8 & 16.9 & -25.7 \\
\hline $\begin{array}{l}\text { Pakistan's } \\
\text { total Exports }\end{array}$ & 9,201.6 & $9,134.6$ & $11,160.2$ & $12,313.3$ & $14,391.0$ & $16,451.2$ & $16,976.2$ & $19,052.0$ \\
\hline$\%$ growth & & -0.7 & 22.2 & 10.3 & 16.9 & 14.3 & 3.2 & 12.2 \\
\hline $\begin{array}{l}\% \text { share of } \\
\text { India }\end{array}$ & 0.6 & 0.5 & 0.6 & 0.7 & 2.0 & 1.8 & 2.0 & 1.3 \\
\hline \multicolumn{9}{|c|}{ Imports } \\
\hline $\begin{array}{l}\text { Imports from } \\
\text { India }\end{array}$ & 235.1 & 186.5 & 166.5 & 384.4 & 551.7 & 801.9 & $1,235.9$ & $1,700.2$ \\
\hline$\%$ growth & & -20.7 & -10.7 & 130.9 & 43.5 & 45.4 & 54.1 & 37.6 \\
\hline $\begin{array}{l}\text { Pakistan's } \\
\text { total Imports }\end{array}$ & $10,728.4$ & $10,339.5$ & $12,230.3$ & $15,591.8$ & $20,598.1$ & $28,580.9$ & $30,540.0$ & $39,966.0$ \\
\hline$\%$ growth & & -3.6 & 18.3 & 27.3 & 32.1 & 38.8 & 6.9 & 30.9 \\
\hline $\begin{array}{l}\% \text { share of } \\
\text { India }\end{array}$ & 2.2 & 1.8 & 1.4 & 2.5 & 2.7 & 2.8 & 4.0 & 4.3 \\
\hline \multicolumn{9}{|c|}{ Total Trade } \\
\hline $\begin{array}{l}\text { Trade with } \\
\text { India }\end{array}$ & 290.5 & 235.7 & 237.0 & 478.1 & 839.8 & $1,095.2$ & $1,578.8$ & $1,955.0$ \\
\hline$\%$ growth & & -18.9 & 0.6 & 101.6 & 75.7 & 30.4 & 44.2 & 23.8 \\
\hline $\begin{array}{l}\text { Pakistan's } \\
\text { total Trade }\end{array}$ & $19,930.0$ & $19,474.1$ & $23,390.5$ & $27,905.1$ & $34,989.1$ & $45,032.1$ & $47,516.2$ & $59,018.0$ \\
\hline$\%$ growth & & -2.3 & 20.1 & 19.3 & 25.4 & 28.7 & 5.5 & 24.2 \\
\hline $\begin{array}{l}\text { \% share of } \\
\text { India }\end{array}$ & 1.5 & 1.2 & 1.0 & 1.7 & 2.4 & 2.4 & 3.3 & 3.3 \\
\hline
\end{tabular}

Source: Ministry of Commerce, Government of Pakistan and Economic Survey. 


\section{Table-A3: Composition of India's Official Imports from Pakistan (Percent)}

Averages

\begin{tabular}{lcccccccccc}
\hline \multirow{3}{*}{ Commodity } & $2001-$ & $2002-$ & $2003-$ & $2004-$ & $2005-$ & $2006-$ & $2007-$ & '00- '04- \\
& 2002 & 2003 & 2004 & 2005 & 2006 & 2007 & 2008 & 04 & 08 \\
\hline
\end{tabular}

Edible fruit and nuts; peel or citrus fruit or melons.

$\begin{array}{lllllllll}4 \% & 20 \% & 21 \% & 24 \% & 15 \% & 27 \% & 15 \% & 11 \% & 20 \%\end{array}$

Mineral fuels, mineral oils and products of their distillation; bituminous substances;

$\begin{array}{lllllllll}0 \% & 0 \% & 0 \% & 0 \% & 0 \% & 36 \% & 23 \% & 0 \% & 15 \%\end{array}$ mineral waxes.

Edible vegetables and certain roots and tubers.

$\begin{array}{lllllllll}42 \% & 28 \% & 44 \% & 5 \% & 38 \% & 0 \% & 0 \% & 39 \% & 11 \%\end{array}$

Vegetable plaiting materials; vegetable products not elsewhere specified or included.

Cotton.

$\begin{array}{lllllllll}0 \% & 0 \% & 0 \% & 1 \% & 0 \% & 15 \% & 16 \% & 0 \% & 8 \%\end{array}$

Silk

$\begin{array}{lllllllll}0 \% & 0 \% & 0 \% & 16 \% & 16 \% & 0 \% & 0 \% & 0 \% & 8 \%\end{array}$

Inorganic chemicals; organic or inorganic compounds of precious metals, of rare-earth metals, or radi. Elem. Or of isotopes.

Salt; sulphur; earths and stone; plastering materials, lime and cement.

Lead and articles thereof. $\begin{array}{lllllllll}0 \% & 0 \% & 0 \% & 0 \% & 0 \% & 0 \% & 11 \% & 0 \% & 3 \%\end{array}$ Organic chemicals

Cereals.

$\begin{array}{lllllllll}0 \% & 0 \% & 0 \% & 0 \% & 0 \% & 2 \% & 8 \% & 0 \% & 3 \%\end{array}$

$1 \% \quad 0 \% \quad 0 \% \quad 0 \% \quad 0 \% \quad 8 \% \quad 1 \% \quad 0 \% \quad 2 \%$

Raw hides and skins (other than furskins) and leather

$2 \% \quad 1 \% \quad 1 \%$

$0 \%$

$4 \% \quad 1 \% \quad 2 \%$

$1 \% \quad 1 \% \quad 2 \% \quad 0 \%$

$1 \% \quad 4 \% \quad 1 \% \quad 2 \%$

Wool, fine or coarse animal hair, horsehair yarn and woven fabric.

Plastic and articles thereof.

$1 \% \quad 0 \% \quad 0 \%$

$0 \% \quad 1 \% \quad 2 \% \quad 1 \% \quad 1 \%$

Coffee, tea, mate and spices.

$0 \% \quad 3 \% \quad 6 \% \quad 1 \% \quad 1 \% \quad 1 \% \quad 1 \% \quad 2 \% \quad 1 \%$

Products of the milling industry; malt; starches; inulin; $\quad 6 \% \quad 5 \% \quad 3 \% \quad 2 \% \quad 1 \% \quad \begin{array}{llllll}1 \% & 0 \% & 4 \% & 1 \%\end{array}$ wheat gluten. 
Oil seeds and olea. Fruits; misc. Grains, seeds and fruit; industrial or medicinal plants; straw and fodder.

Man-made staple fibres.

$\begin{array}{lllllllll}0 \% & & 0 \% & 1 \% & 0 \% & 0 \% & 1 \% & 0 \% & 1 \% \\ 0 \% & 0 \% & 1 \% & 0 \% & 0 \% & 1 \% & 1 \% & 1 \% & 1 \% \\ 10 \% & & 0 \% & 0 \% & 0 \% & 0 \% & 0 \% & 5 \% & 0 \%\end{array}$

Lac; gums, resins and other vegetable saps and extracts.

Other made up textile articles; sets; worn clothing and worn textile articles; rags

Miscellaneous chemical products.

$\begin{array}{lllllllll}0 \% & 0 \% & 5 \% & 0 \% & 0 \% & 0 \% & 0 \% & 1 \% & 0 \%\end{array}$

Fish and crustaceans, molluscs and other aquatic invertabrates.

$\begin{array}{llllllll}0 \% & 0 \% & 0 \% & 0 \% & 0 \% & 0 \% & 0 \% & 0 \%\end{array}$

Essential oils and resinoids; perfumery, cosmetic or toilet preparations.

$\begin{array}{llllllll}0 \% & 5 \% & 0 \% & 0 \% & 0 \% & 0 \% & 3 \% & 0 \%\end{array}$

Products of animal origin, not elsewhere specified or $11 \% \quad 0 \%$ $\begin{array}{llllll}0 \% & 0 \% & 0 \% & 0 \% & 6 \% & 0 \%\end{array}$ included.

Preparations of meat, of fish or of crustaceans, molluscs or other aquatic invertebrates

$2 \% \quad 0 \% \quad 0 \% \quad 0 \% \quad 0 \% \quad 0 \% \quad 0 \% \quad 1 \% \quad 0 \%$

Animal or vegetable fats and oils and their cleavage products; pre. Edible fats; $\begin{array}{llllllll}4 \% & 1 \% & 1 \% & 0 \% & 0 \% & 0 \% & 2 \% & 0 \%\end{array}$ animal or vegetable waxes.

Sugars and sugar confectionery.

$\begin{array}{rrrrrrrrr}5 \% & 33 \% & 0 \% & 0 \% & 0 \% & 0 \% & 0 \% & 17 \% & 0 \% \\ 6 \% & 2 \% & 5 \% & 13 \% & 10 \% & 5 \% & 9 \% & 0 \% & 7 \%\end{array}$

All others

Source: Compiled from data on Department of Commerce, Government of India. http://commerce.nic.in. 


\section{Table-A4: Composition of India's Official Exports to Pakistan (Percent)}

Averages

\begin{tabular}{|c|c|c|c|c|c|c|c|c|c|}
\hline Commodity & $\begin{array}{l}2001- \\
2002\end{array}$ & $\begin{array}{l}2002- \\
2003\end{array}$ & $\begin{array}{l}2003- \\
2004\end{array}$ & $\begin{array}{l}2004- \\
2005\end{array}$ & $\begin{array}{l}2005- \\
2006\end{array}$ & $\begin{array}{l}2006- \\
2007\end{array}$ & $\begin{array}{l}2007- \\
2008\end{array}$ & $\begin{array}{c}00- \\
04\end{array}$ & $\begin{array}{c}04- \\
08\end{array}$ \\
\hline Organic chemicals & $5 \%$ & $4 \%$ & $35 \%$ & $40 \%$ & $0 \%$ & $0 \%$ & $25 \%$ & $11 \%$ & $16 \%$ \\
\hline Pharmaceutical products & $0 \%$ & $0 \%$ & $2 \%$ & $1 \%$ & $30 \%$ & $21 \%$ & $1 \%$ & $1 \%$ & $13 \%$ \\
\hline Cotton. & $0 \%$ & $0 \%$ & $18 \%$ & $3 \%$ & & $0 \%$ & $23 \%$ & $5 \%$ & $9 \%$ \\
\hline Sugars and sugar confectionery. & $0 \%$ & $0 \%$ & $1 \%$ & $0 \%$ & $4 \%$ & $26 \%$ & $4 \%$ & $3 \%$ & $9 \%$ \\
\hline $\begin{array}{l}\text { Mineral fuels, mineral oils and } \\
\text { products of their distillation; } \\
\text { bituminous substances; mineral } \\
\text { waxes. }\end{array}$ & $3 \%$ & $3 \%$ & $0 \%$ & $11 \%$ & $3 \%$ & $2 \%$ & $13 \%$ & $3 \%$ & $7 \%$ \\
\hline Man-made filaments. & $0 \%$ & $0 \%$ & $0 \%$ & $0 \%$ & $8 \%$ & $15 \%$ & $2 \%$ & $0 \%$ & $6 \%$ \\
\hline $\begin{array}{l}\text { Tobacco and manufactured } \\
\text { tobacco substitutes. }\end{array}$ & $0 \%$ & $9 \%$ & $9 \%$ & $8 \%$ & $8 \%$ & $5 \%$ & $0 \%$ & $9 \%$ & $5 \%$ \\
\hline $\begin{array}{l}\text { Raw hides and skins (other than } \\
\text { furskins) and leather }\end{array}$ & $0 \%$ & $0 \%$ & $0 \%$ & $0 \%$ & $7 \%$ & $8 \%$ & $0 \%$ & $0 \%$ & $4 \%$ \\
\hline Plastic and articles thereof. & $0 \%$ & $0 \%$ & $2 \%$ & $7 \%$ & $0 \%$ & $0 \%$ & $5 \%$ & $1 \%$ & $3 \%$ \\
\hline $\begin{array}{l}\text { Edible vegetables and certain } \\
\text { roots and tubers. }\end{array}$ & $4 \%$ & $4 \%$ & $0 \%$ & $1 \%$ & $4 \%$ & $3 \%$ & $3 \%$ & $2 \%$ & $3 \%$ \\
\hline Rubber and articles thereof. & $0 \%$ & $0 \%$ & $5 \%$ & $6 \%$ & $1 \%$ & $0 \%$ & $3 \%$ & $1 \%$ & $2 \%$ \\
\hline $\begin{array}{l}\text { Articles of leather, saddlery and } \\
\text { harness; travel goods, handbags } \\
\text { and similar cont. articles of } \\
\text { animal gut(othr thn silk- } \\
\text { wrm)gut. }\end{array}$ & & $0 \%$ & $0 \%$ & $0 \%$ & $6 \%$ & $3 \%$ & $0 \%$ & $0 \%$ & $2 \%$ \\
\hline Coffee, tea, mate and spices. & $2 \%$ & $2 \%$ & $3 \%$ & $3 \%$ & $2 \%$ & $2 \%$ & $2 \%$ & $2 \%$ & $2 \%$ \\
\hline Copper and articles thereof. & $0 \%$ & $0 \%$ & $0 \%$ & $0 \%$ & $5 \%$ & $2 \%$ & $0 \%$ & $0 \%$ & $2 \%$ \\
\hline $\begin{array}{l}\text { Residues and waste from the } \\
\text { food industries; prepared } \\
\text { animal fodder. }\end{array}$ & $4 \%$ & $9 \%$ & & $0 \%$ & & $0 \%$ & $5 \%$ & $4 \%$ & $2 \%$ \\
\hline Iron and steel & $0 \%$ & & $3 \%$ & $3 \%$ & $0 \%$ & $0 \%$ & $2 \%$ & $1 \%$ & $1 \%$ \\
\hline Ores, slag and ash. & $16 \%$ & $22 \%$ & $3 \%$ & $4 \%$ & $1 \%$ & $0 \%$ & $1 \%$ & $10 \%$ & $1 \%$ \\
\hline $\begin{array}{l}\text { Inorganic chemicals; organic or } \\
\text { inorganic compounds of } \\
\text { precious metals, of rare-earth } \\
\text { metals, or radi. Elem. Or of } \\
\text { isotopes. }\end{array}$ & $0 \%$ & $0 \%$ & $0 \%$ & $1 \%$ & $3 \%$ & $1 \%$ & $0 \%$ & $0 \%$ & $1 \%$ \\
\hline
\end{tabular}


Oil seeds and olea. Fruits; misc.

Grains, seeds and fruit; industrial or medicinal plants; straw and fodder.

Essential oils and resinoids; perfumery, cosmetic or toilet preparations.

$\begin{array}{lllllllll}0 \% & 0 \% & 5 \% & 1 \% & 2 \% & 1 \% & 1 \% & 9 \% & 1 \%\end{array}$

Tanning or dyeing extracts; tannins and their deri. Dyes, pigments and other colouring matter; paints and ver; putty and other mastics; inks.

Meat and edible meat offal.

$\begin{array}{lllllllll}0 \% & 0 \% & 4 \% & 2 \% & 0 \% & 0 \% & 2 \% & 1 \% & 1 \% \\ & & & & & & & & \\ 0 \% & 0 \% & & 0 \% & 1 \% & 2 \% & 1 \% & 0 \% & 1 \% \\ 0 \% & 0 \% & 1 \% & 1 \% & 0 \% & & 1 \% & 0 \% & 1 \%\end{array}$
products.

$\begin{array}{lllllllll}0 \% & 0 \% & 0 \% & 0 \% & 3 \% & 2 \% & 0 \% & 2 \% & 1 \%\end{array}$

Electrical machinery and equipment and parts thereof; sound recorders and reproducers, television image $\begin{array}{lllllllll}0 \% & 0 \% & 0 \% & 0 \% & 1 \% & 1 \% & 0 \% & 0 \% & 1 \%\end{array}$ and sound recorders and reproducers, and parts.

Products of animal origin, not elsewhere specified or included

\begin{tabular}{lllllllll}
$1 \%$ & $0 \%$ & $0 \%$ & $0 \%$ & $0 \%$ & $0 \%$ & & $2 \%$ & $0 \%$ \\
$0 \%$ & $0 \%$ & $0 \%$ & $0 \%$ & $0 \%$ & $0 \%$ & $0 \%$ & $0 \%$ & $0 \%$ \\
$0 \%$ & $0 \%$ & $0 \%$ & $0 \%$ & $0 \%$ & $0 \%$ & $0 \%$ & $-3 \%$ & $-3 \%$ \\
\hline
\end{tabular}

Project goods; some special uses.

All Others

on

Source: Compiled from data on Department of Commerce, Government of India. http://commerce.nic.in. 


\section{References}

Baroncelli, E. (2007). The Peace Dividend: SAFTA, and Pakistan-India Trade. In The Challenges and Potential of Pakistan-India Trade, eds. Naqvi, Z.F., and Schuler, P., Washington, DC: The World Bank, South Asia Region.

Batra, A. (2004). India's Global Trade Potential: the Gravity Model Approach. Working paper No. 151, Indian Council for Research on International Economic Relations, New Delhi.

Federation of Indian Chambers of Commerce and Industry (2003). Status Paper, India-Pakistan Economic Relations. New Delhi.

Federal Bureau of Statistics, (1997). 50 Years of Pakistan in Statistics, 19471972. Statistics Division, Government of Pakistan, Karachi, Pakistan.

Government of Pakistan (1996). Pakistan-India Trade: Transition to the GATT Regime. Report of the Ministry of Commerce, Islamabad.

Khan, S.R., Yusuf, M., Bokhari, S., and Aziz, S. (2007). Quantifying Informal Trade Between Pakistan and India. In The Challenges and Potential of Pakistan-India Trade, eds. Naqvi, Z.F., and Schuler, P., Washington, DC: The World Bank, South Asia Region.

Nabi, I., and Nasim, A. (2001). Trading With the Enemy: A Case for Liberalizing Pakistan-India Trade. In Regionalism and Globalization: Theory and Practice, ed. Lahiri, S., London: Routledge.

Naqvi, Z.F., and Schuler, P. eds., (2007) The Challenges and Potential of Pakistan-India Trade. Washington, DC: The World Bank, South Asia Region.

Sangani, K., and Schaffer, T. (2003). India-Pakistan Trade: Creating Constituencies for Peace. South Asia Monitor No. 56, Center for Strategic and International Studies, Washington, DC. Available from http://www.csis.org/media/csis/pubs/sam 56.pdf.

State Bank of Pakistan (2006). Implications of Liberalizing Trade and Investment with India. Report from the Research and Economic Policy Departments, Islamabad. Available from http://www.sbp.org.pk/publications/pak-india-trade/. 
Taneja, N. (2007). Paksitan-India Trade: The View from the Indian Side. In The Challenges and Potential of Pakistan-India Trade, eds. Naqvi, Z.F., and Schuler, P., Washington, DC: The World Bank, South Asia Region. 